\title{
Evaluation of Process Risks in IndUSTRY 4.0 ENVIRONMENT
}

\author{
Michaela Švingerová, Martin Melichar
}
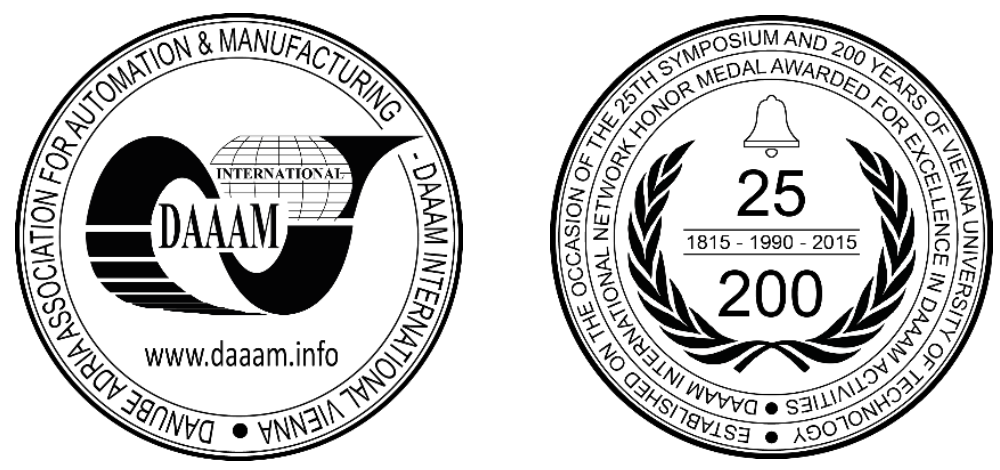

This Publication has to be referred as: Svingerova, M[ichaela] \& Melichar, M[artin] (2017). Evaluation of Process Risks in Industry 4.0 Environment, Proceedings of the 28th DAAAM International Symposium, pp.1021-1029, B. Katalinic (Ed.), Published by DAAAM International, ISBN 978-3-902734-11-2, ISSN 1726-9679, Vienna, Austria DOI: $10.2507 / 28$ th.daaam.proceedings. 142

\begin{abstract}
Industry 4.0 has recently become a frequent topic at a number of expert conferences and even in the mass media. It is typically discussed in the context of process productivity improvement but also in relation to the fear of job losses. The situation is unprecedented where for the first time in history white-collar jobs are under threat and high-qualification professional class faces the prospect of economic decline. This paper reviews Industry 4.0 from the perspective of benefits and risks which are not related to societal aspects but exclusively to serial production data from the automotive industry. It deals with implementation and evaluation of the effect of substitution of human labour upon RPN (risk priority number) indicators which are used for process classification in the PFMEA (Process Failure Mode Effects Analysis) method as required by the IATF 16949 (International Automotive Task Force) international automotive standard. The article describes the PFMEA method, the inputs and analyses the inputs and outputs of the FMEA method in a real-world environment.
\end{abstract}

Keywords: Industry 4.0; PFMEA; Risk

\section{Introduction}

In today's industrial production, process risk assessment by means of PFMEA is one of the cornerstones of control processes in most companies. The earlier automotive standard version, ISO TS 16949, merely recommended FMEA as an appropriate tool for companies involved in the automotive supply chain to master their preventive measures. Its revision and transformation into IATF 16949 and linking to an equally updated version of ISO 9001:2015, the role of risk management was greatly strengthened. IATF-certified companies are required to identify and assess the risks of all company processes on a regular basis as part of their internal management system. Now, the FMEA or PFMEA tool is not just recommended but expressly required by this standard.

The history of FMEA goes back to the 1940s when the U.S. Army sought a technique for eliminating errors in the machines and equipment in use. 1960s saw the the first non-military use of this method when NASA (National Aeronautics and Space Administration) began to use FMEA to identify potential risks in Apollo and Gemini programmes. The truly civilian era of risk assessment began 10 years later when the method was adopted by the automotive industry, particularly the Ford company in an attempt to address the low quality of its Ford Pinto model.

PFMEA is a team-based approach to potential risk assessment where the multidisciplinary team is usually led by the engineer who is responsible for the product design. Active involvement of representatives of all areas concerned is 
expected, including assembly, production, design, testing and others [7]. It is advisable to begin risk mapping with a flow chart of the process in order to map it clearly and identify its boundaries. The customer is typically the end user but, depending on the definition, it may comprise the downstream operation or subsequent assembly operation.

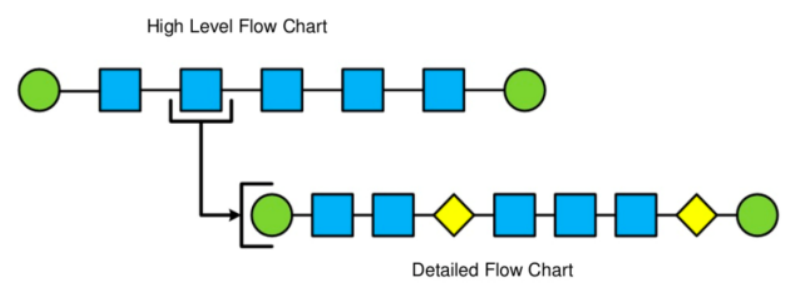

Fig. 1. Flow chart [10]

Once the process and its boundaries have been clearly defined, brainstorming, Ishikawa diagram or other tools are used to identify as many risks as possible which may threaten the process[2;6]. These risks are then evaluated according to a consistent method from three aspects: severity of consequences in respect of the customer, occurrence of consequences in respect of the customer and the chance of detection. Each of these aspects is assigned a score on a scale from 1 to 10 as indicated in the tables below.

\begin{tabular}{|c|c|c|}
\hline Consequence & Severity in respect of the customer & Score \\
\hline \multirow{2}{*}{$\begin{array}{c}\text { Failure to meet safety of regulatory } \\
\text { requirements }\end{array}$} & Affects safe operation without warning & 9 \\
\cline { 2 - 3 } Impaired or lost primary function & Affects safe operation after warning & 8 \\
\cline { 2 - 3 } Impaired or lost secondary function & Vehicle disabled & 7 \\
\cline { 2 - 3 } & Vehicle drivable, reduced power & 5 \\
\hline \multirow{2}{*}{ Inconvenience } & Loss of comfort & 4 \\
\hline & Reduced comfort & 3 \\
\cline { 2 - 3 } & Noticed by 75\% of customers $50 \%$ of customers & 2 \\
\cline { 2 - 3 } & Noticed by 25\% of customers & 1 \\
\hline
\end{tabular}

Table 1. FMEA - severity [10]

\begin{tabular}{|c|c|c|}
\hline Consequence & Occurrence in respect of the customer & Score \\
\hline Major & $100000 \mathrm{ppm}$ & 9 \\
\hline \multirow{2}{*}{ Medium } & $50000 \mathrm{ppm}$ & 8 \\
& $20000 \mathrm{ppm}$ & 7 \\
\cline { 2 - 3 } & $10000 \mathrm{ppm}$ & 6 \\
\cline { 2 - 3 } & $2000 \mathrm{ppm}$ & 5 \\
\hline \multirow{2}{*}{ Medium } & $500 \mathrm{ppm}$ & 4 \\
\cline { 2 - 3 } & $100 \mathrm{ppm}$ & 3 \\
\cline { 2 - 3 } & $10 \mathrm{ppm}$ & 2 \\
\hline \multirow{2}{*}{ Low } & $1 \mathrm{ppm}$ & 1 \\
\hline
\end{tabular}

Table 2. FMEA - occurrence [10]

\begin{tabular}{|c|c|c|}
\hline Chance of detection & Probability of identification of the cause & Score \\
\hline Detection impossible & Cannot be detected & 10 \\
\hline Near impossible & Low probability of detection & 9 \\
\hline \multirow[t]{2}{*}{ Negligible } & E.g. visual inspection & 8 \\
\hline & \multirow[t]{2}{*}{ Detection of the problem in the workplace } & \multirow[t]{2}{*}{7} \\
\hline Very low & & \\
\hline Low & $\begin{array}{c}\text { Measurement after the operation was completed } \\
\text { by the operator }\end{array}$ & 6 \\
\hline Medium & $\begin{array}{l}\text { Detection by operator with the aid of automated } \\
\text { tools }\end{array}$ & 5 \\
\hline Medium to high & Inspection with automated tools and separation & 4 \\
\hline High & Inspection with automated tools and separation & 3 \\
\hline Very high & Automated tools for error detection & 2 \\
\hline Fault prevention & Error prevention & 1 \\
\hline
\end{tabular}

Table 3. FMEA - identification [10] 
After the assessment, risk priority numbers (RPN) are determined for individual risks by simple multiplication of values for all three aspects. Risks with RPN values higher than an internal or contractual limit and those with the greatest severity are addressed on a priority basis as part of prevention measures.

\section{Experimental Procedure}

\subsection{Real case study}

This paper describes an assessment of automation of production using real-world data from a company which operates in the automotive industry. The data comes from serial production of canned catalysts. Two production lines were compared. Both of them are currently used in production. The one which has not been automated yet has been in operation for several years with minor improvements gradually introduced. One year ago, an automated line was installed next to it $[2 ; 3 ; 4]$. In this new line, most operations which used to be performed by a worker/operator are done by a robot. Even this automated line, though, requires the operator to carry out basic infeed and outfeed tasks. The automated line is monitored continuously and its processes are being refined. Such preparations may eventually lead to full automation.

\subsection{Finished product}

The finished products of both lines are canned catalysts. They consist of the monolithic catalyst, a support mat and a steel tube. It should be pointed out that for the purposes of this paper, the canned catalyst is considered the final product, although this only applies to the production lines described here. The end use requires its incorporation into the exhaust system of a vehicle.

The monolithic catalyst is the single most important and most expensive part of the catalytic converter. It is a ceramic cylinder which contains elements such as platinum, rhodium and palladium. It is a very brittle part. In the catalytic converter, its role is to reduce the amount of harmful products in the exhaust gases. This is provided by its sophisticated inner structure which is not identical in all monolithic catalysts. Every car manufacturer and every car model has its specific monolithic catalyst structure and size. The figure below shows various cell structures as seen from the top or bottom side of the monolithic catalyst[1;5;7].

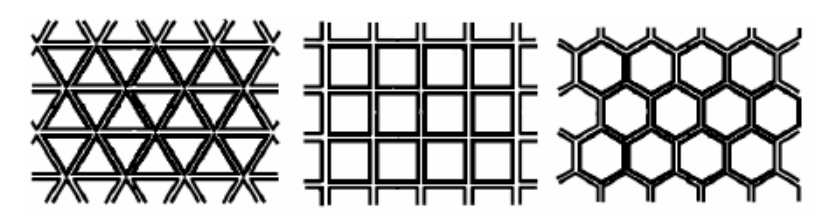

Fig. 2. Example of cell structures [9]

The sizes of monolithic catalysts differ as well, with diameters of approximately $15 \mathrm{~cm}$ and heights around $15 \mathrm{~cm}$ in passenger vehicles. The typical appearance of a monolithic catalyst is shown in the figure below.

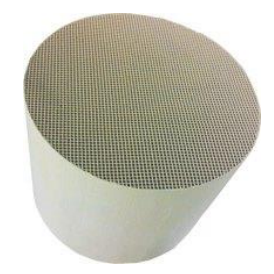

Fig. 3. Monolithic catalyst Source: Internal company documents

The support mat in the canned catalyst is made of glass wool. It provides both thermal and noise insulation and protects the brittle monolithic catalyst from damage. Shapes of the support mat can differ, as illustrated below, but the insulation effect must remain.

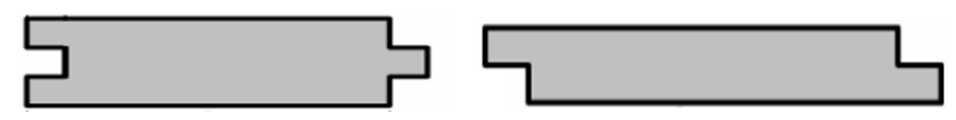

Fig. 4. Detail of isolation [9]

To give an idea of the glass wool texture, the diagram below shows the classification of fibres of which the insulation is composed. 


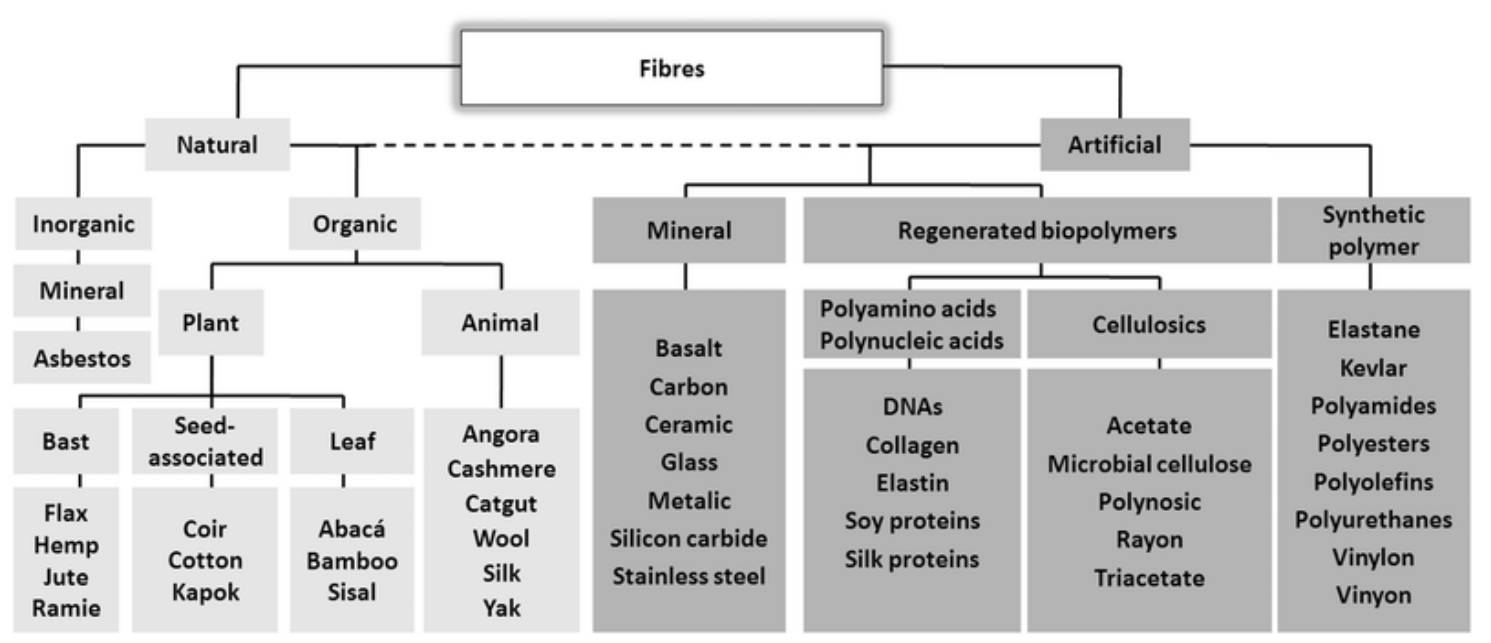

Fig. 5. Fibres classification [9]

The last part of the canned catalyst is its outer shell. It is in fact an iron tube. The first step involves rolling up sheet metal to a cylinder shape and laser welding it together in the machine. The resulting tube is cut by laser to the desired lengths to be used as "cans" for the catalytic converter. This part is shown in the figure below, on the left. The article in the centre is the monolithic catalyst and the one on the right is the rolled-up support mat. The figure below them shows a $3 \mathrm{D}$ rendering of the completed canned catalyst.

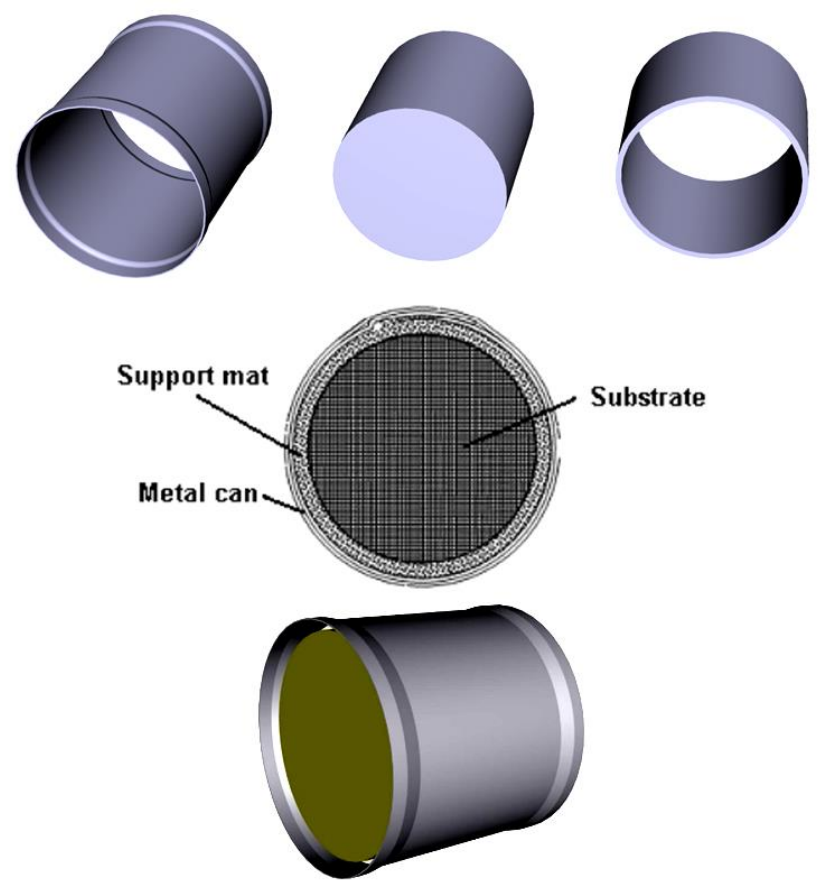

Fig. 6. Canned catalyst [9]

\subsection{Production process}

The sequence for making the canned catalyst is obvious from the parts used. The process flow below indicates the individual steps.

The automated line will be considered first. The boxes to the right of and below the dotted rectangle in the process flow chart indicate the operations which are done by human operator even in the automated line. They include feeding individual parts to the machine, final inspection, and transfer to downstream lines for final processing. Inside the dotted rectangle, there are the operations which are performed by the machine. 


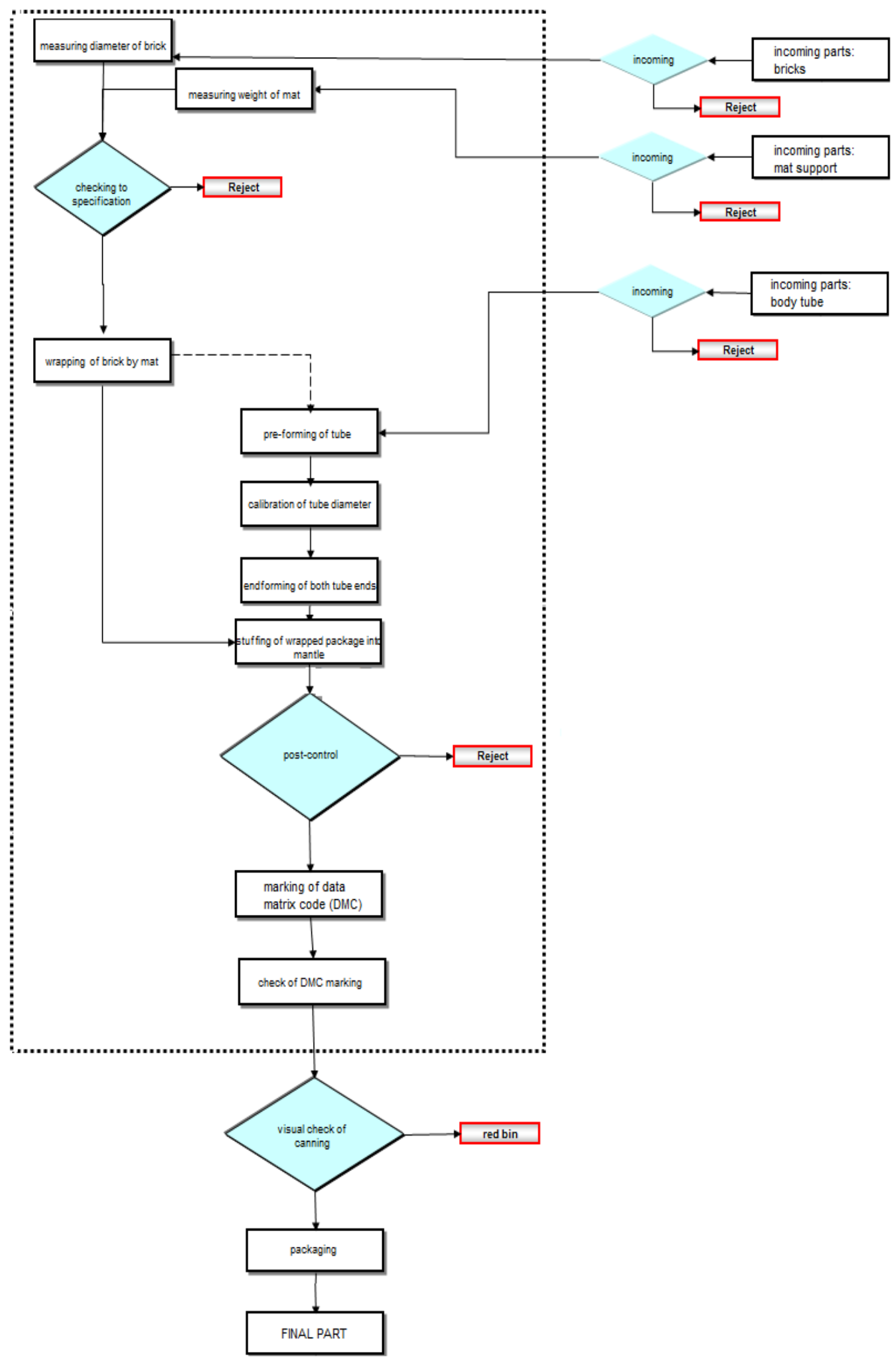

Fig. 7. Making catalyst schema [9]

The photograph (Fig. 9) below the flow chart shows the "Kirschenhofer Maschinen" automated canning line. 


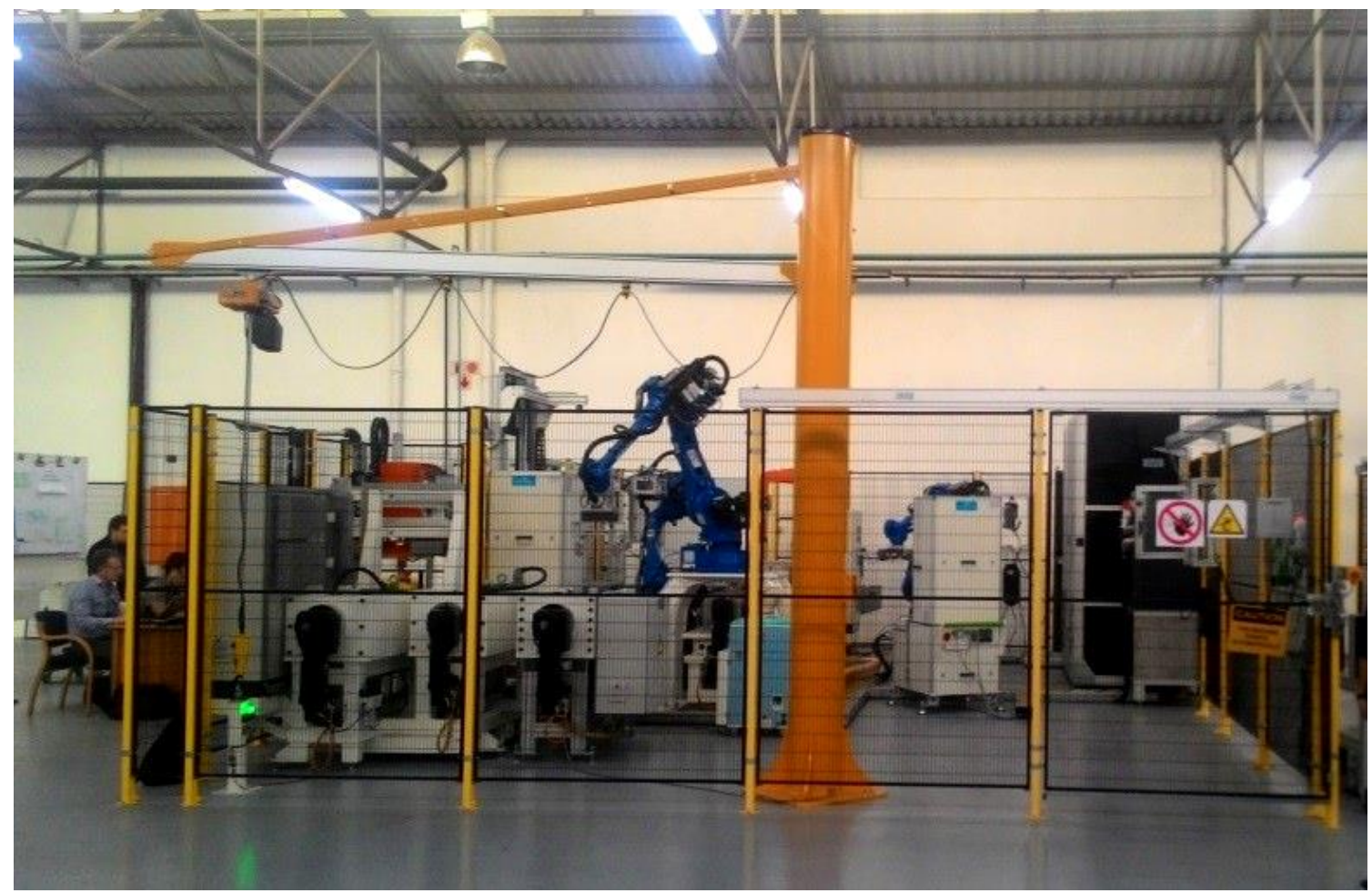

Fig. 8. Robotics work place [9]

In the conventional canning line, all the operations indicated in the flow chart are carried out by a human operator in several work stations with production machines and respective control computers [8]. Today, this conventional line is only used occasionally, on a customer request, typically for making small batches of canned catalysts. Due to confidentiality restrictions, the photograph of this conventional line - referred to as "shrinking line" - cannot be shown.

\section{FMEA analysis}

\subsection{Manual operator}

\begin{tabular}{|c|c|c|c|c|c|c|c|c|c|c|c|}
\hline \multirow{2}{*}{$\begin{array}{l}\text { बे } \\
\text { है } \\
\text { है } \\
\text { के } \\
\text { के }\end{array}$} & \multicolumn{2}{|l|}{\begin{tabular}{|l|} 
Process \\
Function
\end{tabular}} & \multirow{2}{*}{ Potential Failure Mode } & \multirow{2}{*}{$\begin{array}{c}\text { Potential Effect(s) of } \\
\text { Failure }\end{array}$} & \multirow{2}{*}{ 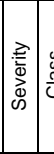 } & \multirow{2}{*}{$\begin{array}{c}\text { Potential Cause(s)/ } \\
\text { Mechanism(s) of } \\
\text { Failure }\end{array}$} & \multirow[t]{2}{*}{$\mid$} & \multirow{2}{*}{$\begin{array}{l}\text { Current Process } \\
\text { Controls } \\
\text { Prevention }\end{array}$} & \multirow{2}{*}{$\begin{array}{c}\text { Current Process Controls } \\
\text { Detection }\end{array}$} & \multirow{2}{*}{ 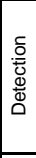 } & \multirow{2}{*}{ 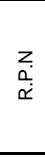 } \\
\hline & Operation & Item. & & & & & & & & & \\
\hline \multirow[t]{6}{*}{1} & \multirow[t]{6}{*}{$\begin{array}{c}\text { Components } \\
\text { loading into } \\
\text { the machine }\end{array}$} & \multirow[t]{6}{*}{ netr. } & Wrong part orientation & Improper fit to vehicle & 7 & \begin{tabular}{|l|} 
Operator mistake, \\
Standardize working \\
instruction not \\
followed
\end{tabular} & 4 & \begin{tabular}{|l} 
Process steps \\
description in \\
Standardize work \\
instruction
\end{tabular} & $\begin{array}{l}\text { sensors control correct } \\
\text { orientation }\end{array}$ & 2 & 56 \\
\hline & & & Insuficient part position & $\begin{array}{l}\begin{array}{l}\text { Tooling damage, time } \\
\text { loss }\end{array} \\
\end{array}$ & 8 & \begin{tabular}{|l|} 
Operator mistake, \\
Standardize working \\
instruction not \\
followed
\end{tabular} & 4 & \begin{tabular}{|l|} 
Process steps \\
description in \\
Standardize work \\
instruction, pin is \\
controling correct \\
position (sensor on \\
end stop)
\end{tabular} & \begin{tabular}{|l|} 
pin is controling correct \\
position (sensor on end \\
stop)
\end{tabular} & 3 & 96 \\
\hline & & & \begin{tabular}{|l|} 
Insufficient part position ( \\
\end{tabular} & \begin{tabular}{|l|} 
Tooling damage, time \\
loss
\end{tabular} & 8 & \begin{tabular}{|l|} 
Operator mistake, \\
Standardize working \\
instruction not \\
followed
\end{tabular} & 4 & \begin{tabular}{|l|} 
Process steps \\
description in \\
Standardize work \\
instruction
\end{tabular} & \begin{tabular}{|l} 
visual control, operator \\
has to ensure position \\
with small equipment
\end{tabular} & 5 & 160 \\
\hline & & & missing component & Improper fit to vehicle & 7 & \begin{tabular}{|l|} 
Operator mistake, \\
Standardize working \\
instruction not \\
followed
\end{tabular} & 4 & \begin{tabular}{|l|} 
Process steps \\
description in \\
Standardize work \\
instruction
\end{tabular} & $\begin{array}{l}\text { sensor checking right } \\
\text { position }\end{array}$ & 5 & 140 \\
\hline & & & \multirow[t]{2}{*}{ extra component } & \multirow[t]{2}{*}{\begin{tabular}{|l} 
Improper fit to vehicle \\
\end{tabular}} & 7 & $\begin{array}{l}\text { component inserted } \\
\text { twice }\end{array}$ & 3 & Work instruction & $\begin{array}{l}\text { install sensor to control } \\
\text { right material thickness } \\
\text { before clamping }\end{array}$ & 3 & 63 \\
\hline & & & & & 7 & $\begin{array}{l}\text { components sticked } \\
\text { with oil }\end{array}$ & 3 & Work instruction & $\begin{array}{l}\text { install sensor to control } \\
\text { right material thickness } \\
\text { before clamping }\end{array}$ & 3 & 63 \\
\hline
\end{tabular}




\begin{tabular}{|c|c|c|c|c|c|c|c|c|c|c|c|}
\hline \multirow[t]{5}{*}{2} & \multirow[t]{5}{*}{ clamping } & \multirow[t]{5}{*}{ clamping parts } & \multirow[t]{5}{*}{ clamp quality } & \multirow[t]{3}{*}{$\begin{array}{l}\text { Part may not meet } \\
\text { system design } \\
\text { requirements }\end{array}$} & 7 & $\begin{array}{l}\text { parts weren't } \\
\text { clamped }\end{array}$ & 4 & operator training & $\begin{array}{l}\text { sensor checking right } \\
\text { position of clamps }\end{array}$ & 4 & 112 \\
\hline & & & & & 7 & $\begin{array}{l}\text { parts weren't } \\
\text { clamped }\end{array}$ & 4 & operator training & $\begin{array}{l}\text { sensors checking right } \\
\text { position of clamps }\end{array}$ & 4 & 112 \\
\hline & & & & & 7 & $\begin{array}{l}\text { parts weren't } \\
\text { clamped }\end{array}$ & 4 & operator training & $\begin{array}{l}\text { sensors checking right } \\
\text { position of clamps }\end{array}$ & 4 & 112 \\
\hline & & & & \multirow[t]{2}{*}{$\begin{array}{l}\text { Part may not meet } \\
\text { system design } \\
\text { requirements }\end{array}$} & 7 & unsifficient clamping & 4 & operator training & $\begin{array}{l}\text { sensor checking right } \\
\text { position of clamps }\end{array}$ & 4 & 112 \\
\hline & & & & & 7 & unsifficient clamping & 4 & operator training & $\begin{array}{l}\text { sensors checking right } \\
\text { position of clamps }\end{array}$ & 4 & 112 \\
\hline 3 & $\begin{array}{l}\text { part } \\
\text { unloading } \\
\text { from the } \\
\text { machine }\end{array}$ & assy & Part damage & Improper fit to vehicle & 6 & Falling of the part & 2 & $\begin{array}{l}\text { Design of the holders } \\
\text { allowing easy part } \\
\text { manipulation }\end{array}$ & Operator training & 8 & 96 \\
\hline \multirow[t]{4}{*}{4} & \multirow[t]{4}{*}{ packaging } & \multirow[t]{3}{*}{ Box } & Wrong Container type & $\begin{array}{l}\text { Time loss, wrong } \\
\text { number of parts }\end{array}$ & 3 & $\begin{array}{l}\text { Material handler } \\
\text { mistake }\end{array}$ & 4 & no control & $\begin{array}{l}\text { Operator training, } \\
\text { packaging instruction }\end{array}$ & 8 & 96 \\
\hline & & & $\begin{array}{l}\text { Wrong number of parts in } \\
\text { container }\end{array}$ & Inventory discrapency & 3 & $\begin{array}{l}\text { Operator mistake, } \\
\text { packaging instruction } \\
\text { not followed }\end{array}$ & 4 & \begin{tabular}{l|} 
Operator training, \\
packaging instruction
\end{tabular} & $\begin{array}{l}\text { Discrapancy for next } \\
\text { station }\end{array}$ & 8 & 96 \\
\hline & & & Missing label & Lost of tracebility & 4 & $\begin{array}{l}\text { Operator did not print } \\
\text { label or forget to } \\
\text { place printed label } \\
\text { on box }\end{array}$ & 4 & $\begin{array}{l}\text { Operator training, } \\
\text { automatic printing } \\
\text { after last piece } \\
\text { inspection }\end{array}$ & $\begin{array}{l}\text { Reading lable on next } \\
\text { process step }\end{array}$ & 4 & 64 \\
\hline & & part condition & skipped operation & Improper fit to vehicle & 7 & operator mistake & 3 & No control & \begin{tabular}{|l|}
$100 \%$ Touchpoint \\
inspection on another \\
work station
\end{tabular} & 7 & 147 \\
\hline
\end{tabular}

Fig. 9. FMEA analysis - manual operator [10]

\subsection{Automated process}

\begin{tabular}{|c|c|c|c|c|c|c|c|c|c|c|c|c|}
\hline 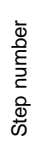 & \multicolumn{2}{|c|}{$\begin{array}{ll}\begin{array}{l}\text { Process } \\
\text { Function }\end{array} \quad \text { Requirements } \\
\end{array}$} & $\begin{array}{l}\text { Potential Failure } \\
\text { Mode }\end{array}$ & $\begin{array}{l}\text { Potential Effect(s) of } \\
\text { Failure }\end{array}$ & 颃 & $\begin{array}{l}0 \\
\mathscr{3} \\
\frac{\pi}{0} \\
0\end{array}$ & $\begin{array}{l}\text { Potential Cause(s)/ } \\
\text { Mechanism(s) of } \\
\text { Failure }\end{array}$ & 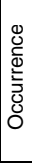 & $\begin{array}{l}\text { Current Process } \\
\text { Controls } \\
\text { Prevention }\end{array}$ & $\begin{array}{c}\text { Current Process Controls } \\
\text { Detection }\end{array}$ & 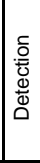 & 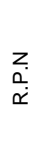 \\
\hline \multirow[t]{6}{*}{1} & \multirow[t]{6}{*}{$\begin{array}{l}\text { Components } \\
\text { loading into } \\
\text { the machine }\end{array}$} & \multirow[t]{6}{*}{$\begin{array}{l}\text { components } \\
\text { (Stamping) }\end{array}$} & $\begin{array}{l}\text { Wrong part } \\
\text { orientation }\end{array}$ & Improper fit to vehicle & 7 & & $\begin{array}{l}\text { Operator mistake, } \\
\text { Standardize working } \\
\text { instruction not } \\
\text { followed }\end{array}$ & 2 & $\begin{array}{l}\text { Process steps } \\
\text { description in } \\
\text { Standardize work } \\
\text { instruction }\end{array}$ & $\begin{array}{l}\text { sensors control correct } \\
\text { orientation }\end{array}$ & 1 & 14 \\
\hline & & & \begin{tabular}{|l} 
Insuficient part \\
position
\end{tabular} & $\begin{array}{l}\text { Tooling damage, time } \\
\text { loss }\end{array}$ & 8 & & $\begin{array}{l}\text { Operator mistake, } \\
\text { Standardize working } \\
\text { instruction not } \\
\text { followed }\end{array}$ & 2 & $\begin{array}{l}\text { Process steps } \\
\text { description in } \\
\text { Standardize work } \\
\text { instruction, pin is } \\
\text { controling correct } \\
\text { position (sensor on } \\
\text { end stop) }\end{array}$ & $\begin{array}{l}\text { pin is controling correct } \\
\text { position (sensor on end } \\
\text { stop) }\end{array}$ & 1 & 16 \\
\hline & & & $\begin{array}{l}\text { Insufficient part } \\
\text { position ( }\end{array}$ & $\begin{array}{l}\text { Tooling damage, time } \\
\text { loss }\end{array}$ & 8 & & $\begin{array}{l}\text { Operator mistake, } \\
\text { Standardize working } \\
\text { instruction not } \\
\text { followed }\end{array}$ & 2 & $\begin{array}{l}\text { Process steps } \\
\text { description in } \\
\text { Standardize work } \\
\text { instruction }\end{array}$ & $\begin{array}{l}\text { visual control, operator } \\
\text { has to ensure position } \\
\text { with small equipment }\end{array}$ & 2 & 32 \\
\hline & & & $\begin{array}{l}\text { missing } \\
\text { component }\end{array}$ & Improper fit to vehicle & 7 & & $\begin{array}{l}\text { Operator mistake, } \\
\text { Standardize working } \\
\text { instruction not } \\
\text { followed }\end{array}$ & 3 & $\begin{array}{l}\text { Process steps } \\
\text { description in } \\
\text { Standardize work } \\
\text { instruction } \\
\end{array}$ & $\begin{array}{l}\text { sensor checking right } \\
\text { position }\end{array}$ & 2 & 42 \\
\hline & & & \multirow[t]{2}{*}{ extra component } & \multirow[t]{2}{*}{ Improper fit to vehicle } & 7 & & $\begin{array}{l}\text { component inserted } \\
\text { twice }\end{array}$ & 2 & Work instruction & $\begin{array}{l}\text { install sensor to control } \\
\text { right material thickness } \\
\text { before clamping }\end{array}$ & 2 & 28 \\
\hline & & & & & 7 & & $\begin{array}{l}\text { components sticked } \\
\text { with oil }\end{array}$ & 2 & Work instruction & $\begin{array}{l}\text { install sensor to control } \\
\text { right material thickness } \\
\text { before clamping }\end{array}$ & 2 & 28 \\
\hline
\end{tabular}




\begin{tabular}{|c|c|c|c|c|c|c|c|c|c|c|c|}
\hline \multirow[t]{5}{*}{2} & \multirow[t]{5}{*}{ clamping } & \multirow[t]{5}{*}{ clamping parts } & \multirow[t]{5}{*}{ clamping quality } & \multirow[t]{3}{*}{\begin{tabular}{|l|} 
Part may not meet \\
system design \\
requirements
\end{tabular}} & 7 & $\begin{array}{l}\text { parts weren't } \\
\text { clamped }\end{array}$ & 2 & operator training & $\begin{array}{l}\text { sensor checking right } \\
\text { position of clamps }\end{array}$ & 2 & 28 \\
\hline & & & & & 7 & $\begin{array}{l}\text { parts weren't } \\
\text { clamped }\end{array}$ & 3 & operator training & $\begin{array}{l}\text { sensors checking right } \\
\text { position of clamps }\end{array}$ & 2 & 42 \\
\hline & & & & & 7 & $\begin{array}{l}\text { parts weren't } \\
\text { clamped }\end{array}$ & 3 & operator training & $\begin{array}{l}\text { sensors checking right } \\
\text { position of clamps }\end{array}$ & 2 & 42 \\
\hline & & & & \multirow[t]{2}{*}{\begin{tabular}{|l|} 
Part may not meet \\
system design \\
requirements
\end{tabular}} & 7 & unsifficient clamping & 3 & operator training & $\begin{array}{l}\text { sensor checking right } \\
\text { position of clamps }\end{array}$ & 2 & 42 \\
\hline & & & & & 7 & unsifficient clamping & 3 & operator training & $\begin{array}{l}\text { sensors checking right } \\
\text { position of clamps }\end{array}$ & 2 & 42 \\
\hline 3 & $\begin{array}{l}\text { part } \\
\text { unloading } \\
\text { from the } \\
\text { machine }\end{array}$ & assy & Part damage & Improper fit to vehicle & 6 & Falling of the part & 2 & \begin{tabular}{|l|} 
Design of the holders \\
allowing easy part \\
manipulation
\end{tabular} & Operator training & 3 & 36 \\
\hline \multirow[t]{4}{*}{4} & \multirow[t]{4}{*}{ packaging } & \multirow[t]{3}{*}{ Box } & $\begin{array}{l}\text { Wrong Container } \\
\text { type }\end{array}$ & $\begin{array}{l}\text { Time loss, wrong } \\
\text { number of parts }\end{array}$ & 3 & $\begin{array}{l}\text { Material handler } \\
\text { mistake }\end{array}$ & 4 & no control & $\begin{array}{l}\text { Operator training, } \\
\text { packaging instruction }\end{array}$ & 8 & 96 \\
\hline & & & $\begin{array}{l}\text { Wrong number of } \\
\text { parts in container }\end{array}$ & Inventory discrapency & 3 & $\begin{array}{l}\text { Operator mistake, } \\
\text { packaging instruction } \\
\text { not followed }\end{array}$ & 4 & $\begin{array}{l}\text { Operator training, } \\
\text { packaging instruction }\end{array}$ & $\begin{array}{l}\text { Discrapancy for next } \\
\text { station }\end{array}$ & 8 & 96 \\
\hline & & & Missing label & Lost of tracebility & 4 & $\begin{array}{l}\text { Operator did not print } \\
\text { label or forget to } \\
\text { place printed label } \\
\text { on box }\end{array}$ & 4 & $\begin{array}{l}\text { Operator training, } \\
\text { automatic printing } \\
\text { after last piece } \\
\text { inspection }\end{array}$ & $\begin{array}{l}\text { Reading lable on next } \\
\text { process step }\end{array}$ & 4 & 64 \\
\hline & & part condition & skipped operation & Improper fit to vehicle & 7 & operator mistake & 3 & No control & \begin{tabular}{|l|}
$100 \%$ Touchpoint \\
inspection on another \\
work station
\end{tabular} & 7 & 147 \\
\hline
\end{tabular}

Fig. 1. FMEA analysis - robot [10]

\subsection{Summary}

An FMEA analysis based on a previous SPC analysis of process stability has clearly shown that substitution of manual operations with an automated process considerably reduced RPN values. The reduction was in the range from 33\% to $84 \%$. The only area where the risk priority number has not changed was the packaging of the part which remained a manual operation even after process automation. The most interesting item in the analysis is the number of critical processes, i.e. the potentially critical ones.

Like its many automotive counterparts, the company has defined its internal RPN acceptance level as 100 . As the analysis shows, appropriately configured automation eliminated seven critical processes which are of major importance to the end user.

\section{Conclusions}

Research team of university of West Bohemia had the goal to analyse influence of risk management connected with replacement human work.

As mentioned in the introduction, today's automotive industry relies in its mandatory risk assessment activities exclusively on the FMEA method which is required by the IATF standard. The method was also used for experimental analysis of a production process, i.e. a substitution of a manual assembly workplace with a robotic cell, an upgrade which can undoubtedly be classified under Industry 4.0. Effects of a specific robotisation step were evaluated in collaboration with researchers from the University of West Bohemia/Regional Technological Institute.

Both processes were evaluated by a multidisciplinary team comprising members from all areas of the production process. Using brainstorming and data from real-world production (which were also utilized in the previous contribution [9]), risks were identified for each process. Each of the risks was classified by the FMEA team from three perspectives: severity/occurrence/detection. Since supply chain experience suggests that setting internal limit RPN values is not effective, this calculation was only use for statistical evaluation and for comparing both groups of results.

The results clearly show that despite the high initial investment costs for introducing an Industry 4.0 workplace, this investment pays off, at least from the risk management perspective. One general finding is that although the robotic cell comprises elements for active detection of errors and integrates a number of features of poka-yoke philosophy, the outcomes are virtually incomparable. RPN values become lower by an order of magnitude, on account of a drop in the detection and occurrence aspects.

The results achieved are in agreement with an earlier experiment, in which this process was assessed from the perspective of capability and stability. Next step in this analyse will be evaluation of risk during mass production inspection. 


\section{Acknowledgements}

This paper was created due to the project GA ZCU v Plzni: SGS-2016-005 "Research and development for innovation in field of Manufacturing processes - Technology of metal cutting II.

\section{References}

[1] Melichar M., Kubátová D., Kutlwašer J.: (2016). CMM measuring cycle and human factor, Proceedings of the 27th DAAAM International Symposium, ISBN 978-3-902734-08-2

[2] Sahno J., Shevtshenko E., Zahharov R.:(2015) Framework for Continuous Improvement of Production Processes and Product Throughput, Procedia Engineering, Volume 100, Pages 511-519, ISSN 1877-7058, http://dx.doi.org/10.1016/j.proeng.2015.01.398.

[3] Hiltmann K.: Predicting Unknown Failures,(2015) Procedia Engineering, Volume 131, Pages 840-849, ISSN $1877-$ 7058, http://dx.doi.org/10.1016/j.proeng.2015.12.392.

[4] Hak Soo Mok, Hyun Su Song, Deuk Jung Kim, Jin Eui Hong, Seung Min Lee, Jung Tae Ahn: Determination of Failure Cause in Remanufacturing,(2015) Procedia Engineering, Volume 100, Pages 14-23, ISSN 1877-7058, http://dx.doi.org/10.1016/j.proeng.2015.01.337.

[5] Chandrajit P., Anand S.: Correlating Failure Mode Effect Analysis (FMEA) \& Overall Equipment Effectiveness (OEE), (2012) Procedia Engineering, Volume 38, Pages 3482-3486, ISSN 1877-7058, http://dx.doi.org/10.1016/j.proeng.2012.06.402.

[6] Xiaoli Zhang, Zhen He, Liangxing Shi, Process Quality Metrics for Mechanical and Electrical Production Lin, (2011), Procedia Engineering, Volume 24, Pages 6-11, ISSN 1877-7058, http://dx.doi.org/10.1016/j.proeng.2011.11.2592.

(http://www.sciencedirect.com/science/article/pii/S1877705811054440)

[7] Vladimir Filaretov, Alexander Zuev, Anatoly Khvalchev, Development of Approach to Automatic Machining of Composite Parts without their Rigid Fixing by Means of Multilink Manipulators, (2014) Procedia Engineering, Volume 69, Pages 4-12, ISSN 1877-7058, http://dx.doi.org/10.1016/j.proeng.2014.02.196. (http://www.sciencedirect.com/science/article/pii/S1877705814001982)

[8] Qi Guo, Kuangjie Sheng, Zheng Wang, Xilin Zhang, hengyi Yang, Rui Miao, Research on Element Importance of Shafting Installation Based on QFD and FMEA,(2017), Procedia Engineering, Volume 174, Pages 677-685, ISSN 1877-7058, http://dx.doi.org/10.1016/j.proeng.2017.01.205.

[9] Faurecia's internal sources

[10] Švingerová M., Melichar M., Evaluation of automated production,( 2017) Pro-tech-ma 